\title{
電子銃解析コードEGN2を用いた電界放出電子ビームのシミュレーション
}

$\begin{array}{llllll}\text { 正員 } & \text { 浅 } & \text { 野 } & \text { 啓 } & \text { 行 } & \text { (三菱電機) } \\ \text { 正 } & \text { 菊 } & \text { 永 } & \text { 敏 } & \text { 之 } & \text { (三菱電機) } \\ \text { 非会貝 } & \text { 森 } & \text { 川 } & \text { 和 } & \text { 敏 } & \text { (三菱電機) }\end{array}$

\section{Simulations of a field emission electron beam with an electron gun analysis program EGN2}

\author{
Hiroyuki Asano,Member(Mitsubishi Electric Corp.), Toshiyuki Kikunaga,Member(Mitsubishi Electric Corp.), \\ Kazutoshi Morikawa,Non-member(Mitsubishi Electric Corp.)
}

\begin{abstract}
We simulated emission currents and electron beam trajectories from a micron size field emitter which consists of an emitter electrode and a gate electrode using the electron gun analysis program EGN2. The parameters such as a height, a half angle and a curvature radius of an emitter electrode influence the emission current significantly. The results of our calculations suggest that the largest emission current occurs when the emitter electrode is as high as the upper surface of the gate electrode and the smaller the half angle is, the larger emission current we have. We also carried out simulations of an electron beam from a field emitter with a focus electrode to reduce a divergence angle of an electron beam. Taking into consideration the existence of a bump at the tip of the emitter electrode, there is a good agreement between calculated and experimental results of the emission current vs. the focus electrode voltage characteristics.
\end{abstract}

キーワード : 真空マイクロエレクトロニクス, 電界放出微小冷陰極, シミュレーション, 電子ビーム,

\section{1.はじめに}

半導体の微細加工技術を用いて，微小な電界放出冷陰極 （以後これを冷陰極と呼ぶ。）を作製し，これを垩子源と するデバイスの実現を目指した真空マイクロエレクトロニ クスが新しい研究分野として注目されている。

冷陰極はこの分野におけるキーパーッであり，エミッタ 電極先端の曲菜半径は数 $10 \mathrm{~nm}$ 以下となるように作製され る。電子は，電極先端付近の非常に強い電界 $\left(>10^{7} \mathrm{~V} / \mathrm{cm}\right)$ による電界放出によって取り出され， $100 \mathrm{~V}$ 程度のゲート 電圧で電子を取り出すことができること, 冷陰極の高集積 化により $100 \mathrm{~A} / \mathrm{cm}^{2}$ 以上の電流密度が期待できることなど 様々な利点を持っている。(1)

本冷陰極の形状には，大別して縦型と横型の 2 種類があ る。縦型は一般に図1に示すような形状をしており，エミ ッ夕電極は円錐形や四角錐形をしている。エミッタの作製 には，蒸着やRIE(Reactive Ion Etching)などの技術が利用 される。

図1の泠院極は1976年にSpindt氏らが発表したものであ る。冷陰極からは，エミッタ・ゲート間電圧 $200 \mathrm{~V} て ゙$ 約 3.2 $\mu \mathrm{A}$ のエミッション電流が得られた。放出電子の電流電圧 特性であるFowler-Nordheimプロットから，電流は電界放 出によるものであることが確認された。また，7000時間に わたって安定に動作した。(2)

Fowler-Nordheimの式を次に示す。

$$
j=\frac{e^{3}}{8 \pi h} \frac{E^{2}}{\phi t^{2}(y)} \exp \left[-\left(\frac{4(2 m)^{1 / 2} \phi^{3 / 2}}{3 \hbar e E} v(y)\right)\right]
$$

ここで, $\mathrm{e}$ は電子の電荷, $\mathrm{m}$ は電子の質量, $\mathrm{h}$ はプランク定 数, $\mathrm{h}=\mathrm{h} / 2 \pi$, Eは電界強度, $\phi$ はエミッ夕電極材料の仕事 関数である。 $\mathrm{t}^{2}(\mathrm{y})$ およびv $(\mathrm{y})\left(こ こ て ゙ ~ y=(e E / 4 \pi \varepsilon)^{1 / 2} / \phi_{0}\right.$ で $\phi_{0}$ は温度および電界強度 0 の時の仕事関数， $\varepsilon_{0}$ は真尘 の誘電率)は鏡像力を考慮した補正項であり， $\mathrm{t}^{2}(\mathrm{y})=1.1$, $\mathrm{v}(\mathrm{y})=\mathbf{0 . 9 5}-\mathrm{y}^{2}$ とすることでよい近似が得られる。 ${ }^{(3)}$ これ より，式(1)は次のようになる。

$$
j=1.5 \times 10^{-6} \frac{E^{2}}{\phi} \exp \left(\frac{10.4}{\phi^{1 / 2}}\right) \times \exp \left(-6.44 \times 10^{7} \phi^{3 / 2} / E\right)
$$

この式からわかるように，電流密度はエミッ夕電極材料 の仕事関数やエミッ夕電極先端付近の電界強度に大きく左 右される。

本冷陰極を利用するにあたっては，その用途によって， できるだけ低電圧で大電流を取り出したい場合や，電子ビ 一ム発散角をできるだけ小さくしたい場合などが考えられ る。それぞれの用途に応じた最適形状の設計には，計算機 シミュレーションが有効であるが, 現在までのところ,こ の分野でのシミュレーションに関する文献例は必ずしも多 くない。米国スタンフォード大学のHerrmannsfeldt氏らは, 同氏の開発した電子銃解析コードEGN2に改良を加えて， 電子源に比して極めて微小な領域からの電界放出による電 子の軌道および放出電流を計算できるようにし，エミッシ ヨン電流を求めている。(4) しかし，素子形状の変化によ りエミッション電流がどのように変化するかといったこと についての系統的な議論がなされておらず，素子形状設計 のために十分な指針を与えるものとはなっていない。また， Mobley氏らやChang氏らは，ゲート電極の上にむう1段の 


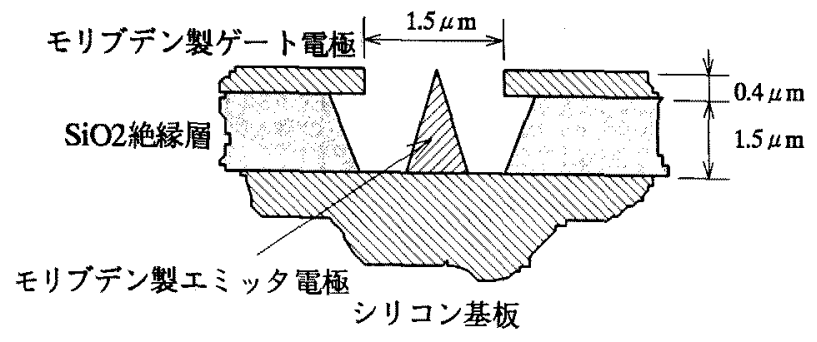

図1 Spindt氏らの縦型冷陰極

Fig.1. Vertical type field emitter by Spindt et al.

電極を備え，これを集束電極として静電レンズの役割を担 わせる構造の冷陰極についてシミュレーションを行い，発 散角の小さい電子ビームの軌道計算結果を得だのが，エミ ッション電流の計算結果と実験結果の比較は行われていな い。

我々は冷陰極に関するさらに詳細な設計指針を得るため に, EGN2(市販版)を用いて, 冷陰極形状がエミッション 電流に与える影響について詳細に調へた。さらに，集束電 極を備えた冷陰極の電子放出特性について, 集束電極電圧 のエミッション電流に与える影響を調へ，実験結果と比較 検討した。

その結果, エミッ夕電極の高さがゲート電極の高さと一 致するときに最も大きなエミッション電流が得られること， エミッ夕電極先端の曲率半径が同一でも電極先端付近の傾 斜が急峻なほど大きなエミッション電流が得られることな どが示された。さらに，集束電極を備えた冷陰極のシミュ レーションでは, エミッタ電極先端に微小な突起があると して計算を行った。このような突起はHerrmannsfeldt氏が, 集束電極を持たない冷陰極の計算の中で取り上げており, 突起を考虑した場合, 1つのエミッ夕電極から故出される 電流値が, 実験で得られる值に近くなることを報告してい る。 (9) 我々は, 集束電極を備えた素子について，エミッ 夕電極先端に同様の突起の存在を仮定し，集束電極電任が エミッション電流に与える影響を調へた。突起先端から電 子が放出されているとし, 突起形状を変えてエミッション 電流を計算した結果, 計算結果と実験結果とがよく一致す る突起形状(高さ $2 \mathrm{~nm}$, 先端曲率半经 $1 \mathrm{~nm}$ 程度)が得られた。 電子放出がエミッ夕電極先端部のさらに微小な部分で起こ ると考えた計算モデルが実験結果をよく説明するというこ とは，電子はエミッ夕電極先端部の限られた場所から放出 されているとするSpindt氏らの考え ${ }^{(2)}$ 支持するむのであ る。

\section{2. エミッ夕電極先端での電子軌道始点の設定方法}

EGN2において，エミッ夕電極先端における電子軌道始 点の設定は自動的に行われるのではなく，利用者に委ねら れている。始点の設定範囲が小さ遇ぎる場合は，エミッシ ョン電流の計算結果が，本来得られるべき值より小さくな り，また，必要以上に広い範国に設定した場合，計算時間 が長くなる。したがって，電子軌道始点範囲の適切な設定

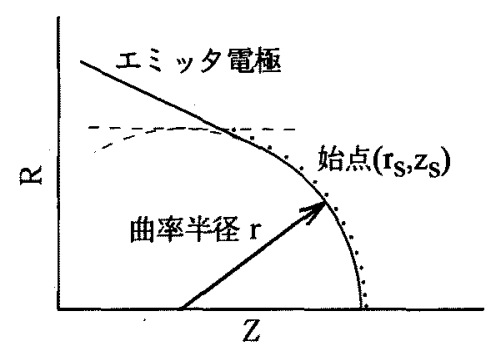

図2 エミッ夕電極先端部付近に設定された電子軌道始点 Fig.2. Starting points of electron trajectories placed near the tip of an emitter electrode.

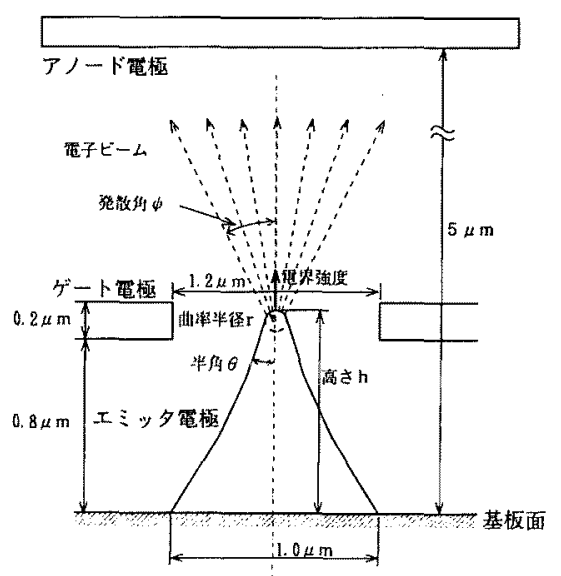

図3計算モデル

Fig.3. A simulation model.

表1 作製されたエミッ夕電極先端の曲率半径の例 $(8)$

Table 1. Examples of a curvature radius of fabricated emitter electrodes

\begin{tabular}{c|l}
\hline エミッ電極先端曲率半徍 & 研究機関 \\
\hline$<20 \mathrm{~nm}$ & 富士通 \\
$<50 \mathrm{~nm}$ & Siemens \\
$23 \mathrm{~nm}$ & 双葉電子 \\
$40 \sim 50 \mathrm{~nm}$ & ミシガン大学 \\
$20 \mathrm{~nm}$ & 新日本製鐵 \\
$10 \mathrm{~nm}$ & NRL \\
\hline
\end{tabular}

が重要である。ここでは, 今回我々が採った設定方法を説 明する。

図2はエミッ夕電極先端部之電子軌道始点の位置関係を 示しており，始点の $(\mathrm{R}, \mathrm{Z})$ 座標を $\left(\mathrm{r}_{\mathrm{S}}, \mathrm{z}_{\mathrm{S}}\right)$ とする。それぞれ の軌道の持つ電流密度は，エミッ夕電極先端から出発した ものが最も大きく，先端から離れるにしたがって小さくな る。始点の R座標値およびエミッ夕電極先端の曲率半径を それぞれ $\mathrm{r}_{\mathrm{S}}, \mathrm{r}$ として， $\mathrm{r}_{\mathrm{S}} \leqq 2 \mathrm{r}$ の範囲に始点を設定した場 合の全エミッション電流值は， $\mathrm{r}_{\mathrm{S}} \leqq \mathrm{r}$ の範囲に始点を設定 したときと同じであったことから， $\mathrm{r}_{\mathrm{S}} \leqq \mathrm{r}$ の範四で始点を 設定することとする。

今後は，各電極間電圧についてはエミッタ電極の電位を 


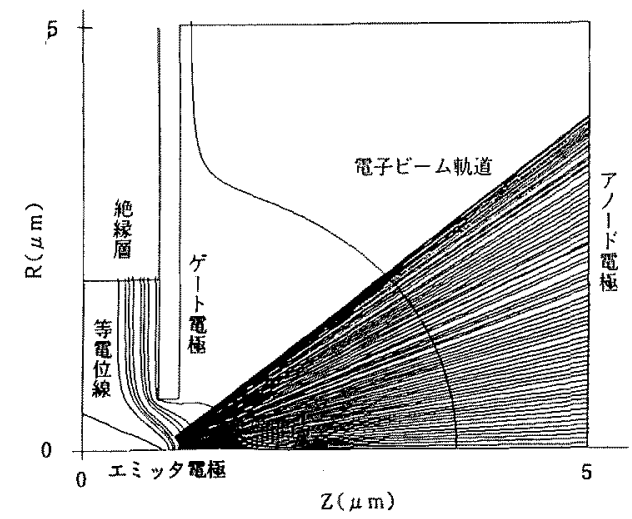

(a) 電子ビームの軌道計算例

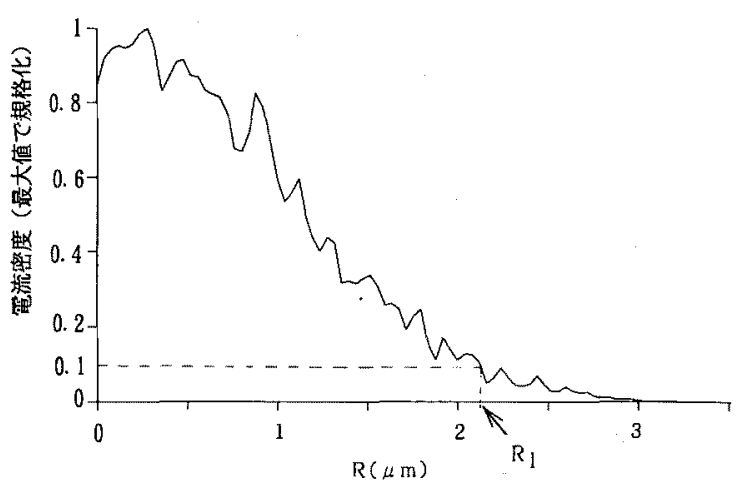

(b) (a)の $\mathrm{Z}=5 \mu \mathrm{m} に お け る$ 電流密度分布

図4電子ビームのシミュレーション結果の例

Fig.4. An example of electron beam simulation.

基準に取り，これに対するゲート電極，アノード電極の電 位をそれぞれゲート電圧，アノード電圧と呼ぶことにする。

3. 1 段ゲート冷除極のシミュレーション

\section{3-1. 計算モデル}

図3に示すようなモデルを用いて計算した。基板面(図3 で斜線で示した部分)からゲート電極の下面までの高さを $0.8 \mu \mathrm{m}$, ゲート電極厚さを $0.2 \mu \mathrm{m}$, ゲート電極開口部直 径を $1.2 \mu \mathrm{m}$, エミッ夕電極底面の直径を $1 \mu \mathrm{m}$, エミッ夕 電極材料の仕事関数を $4.5 \mathrm{eV}$ とする。ミッ夕電極材料之 してはモリブデンやシリコンが一般的であり，これらの材 料の仕事関数は 4.0 から $4.5 \mathrm{eV}$ 程度である。の 基板面から 5 $\mu \mathrm{m}$ の高さの位置に平板電極を置きこれをアノード電極 とする。エミッ夕電極の高さ $\mathrm{h}$, 先端部の半角 $\theta$ ，および 先端の曲率半径 $\mathrm{r}$ をパラメータにとり，これらを変化させ たときの1エミッタあたりのエミッション電流, エミッタ 電極先端部の電界強度, 電子ビームの発散角の変化を求め た。基本となる $\mathrm{h} ， \theta ， \mathrm{r} の$ 值を，それぞれ $0.9 \mu \mathrm{m}$, $29^{\circ}, 20 \mathrm{~nm}$ とする。

$\mathrm{h}=0.9 \mu \mathrm{m}$ のさき，エミッ夕電極の高さが，ゲート電極

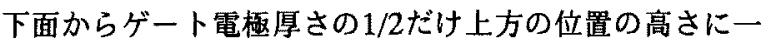
致する。

$\theta=29^{\circ}$ は図3でエミッ夕電極側面の勾配が，先端部の球 面状の部分を除いて一定である場合の值である。

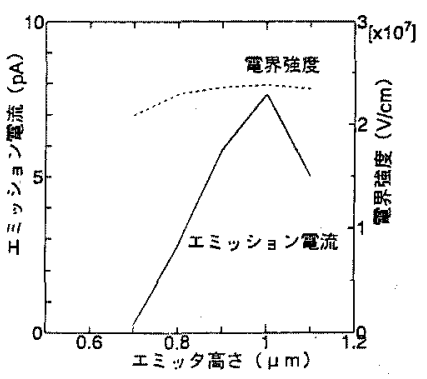

(a)

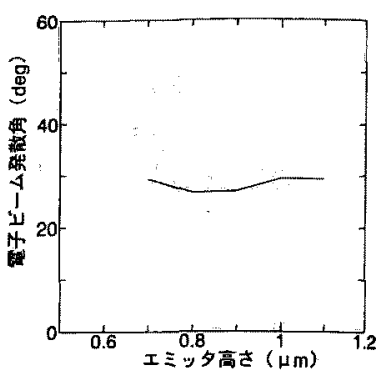

(b)
図5 (a)エミッション電流および電界強度, (b)電子ビーム発散 角のエミッ夕電極高さ依存性

Fig.5.(a)Emission current and electric field,(b)Electron beam divergence angle as a function of the height of an emitter electrode.

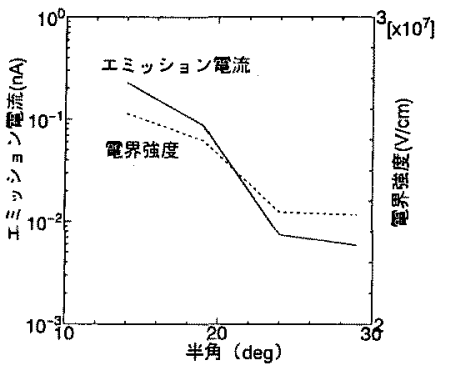

(a)

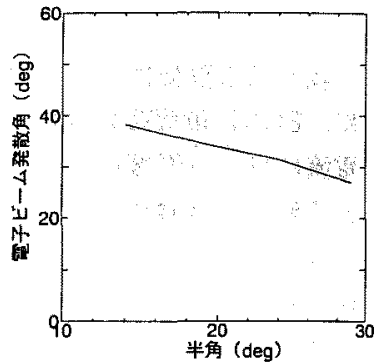

(b)
図6 (a)エミッション電流および電界強度, (b)電子ビ一ム発散 角のエミッ夕電極先端の半角依存性

Fig.6.(a)Emission current and electric field,(b)Electron beam divergence angle as a function of the half angle of an emitter electrode.

$\mathrm{r}$ に関して，作製された泠陰極の主な例を表 1 に示す。 これより $\mathrm{r}=20 \mathrm{~nm}$ は妥当である。

電子ビームのシミュレーション結果の例を図4(a), (b) に示す。図4(a)は電子軌道計算例；(b)は(a)のZ $=5 \mu \mathrm{m} の$ 位置にアノード電極を設定し，そのアノード電極上での

$\mathrm{R}$ 軸方向の電流密度分布を示している。

電子ビームの発散角 $\phi$ を图4を用いて次のように定義す

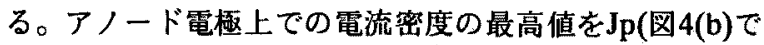
はJp=1)とし，電流密度がJp/10(図4(b)ではJ $/ 10=0.1$ )に なる最大の $\mathrm{R}$ 座標を $\mathrm{R}_{1}$ とする。エミッ夕電極先端からア

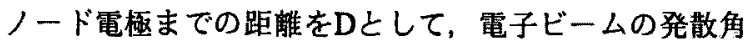
$\phi$ を次式から求める。

$$
\phi=\tan ^{-1}\left[\mathrm{R}_{1} / \mathrm{D}\right]
$$

\section{3-2.計算結果}

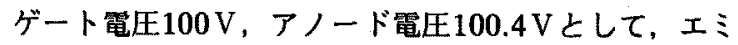
ッション電流，エミッ夕電極先端部の電界強度，電子ビ 一ムの発散角のエミッ夕電極形状に対する依存性を調一 た。図5(a), (b)に半角 $\theta=29^{\circ}$, 曲率半径 $\mathrm{r}=20 \mathrm{~nm}$ で一 定とし，エミッ夕電極の高さ $\mathrm{h}$ を変化させた場合を，図6 (a), (b) K, 高さ $\mathrm{h}=0.9 \mu \mathrm{m}$, 曲率半径 $\mathrm{r}=20 \mathrm{~nm}$ で一定と 


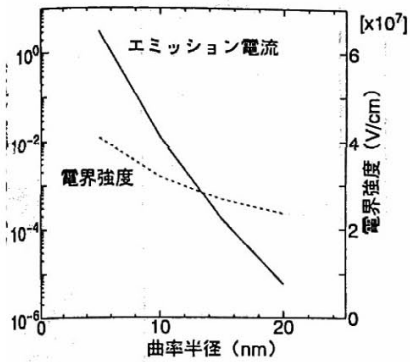

(a)

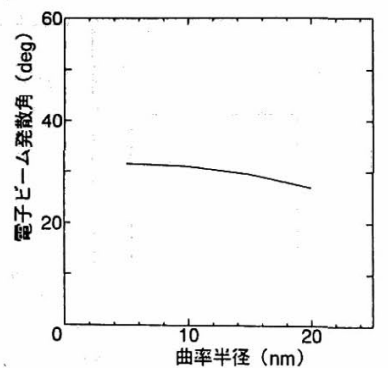

(b)
図7 (a)エミッション電流および電界強度, (b)電子ビーム発散 角のエミッ夕電極先端曲率半径依存性

Fig.7. (a)Emission current and electric field,(b)Electron beam divergence angle as a function of the curvature radius of an emitter electrode.

し, 半角 $\theta$ を変化させた場合を, 図7(a), (b)に, 高さ $\mathrm{h}=$ $0.9 \mu \mathrm{m}$, 半角 $\theta=29^{\circ}$ で一定とし, 曲率半径 $\mathrm{r}$ を变化させ た場合をそれぞれ示す。

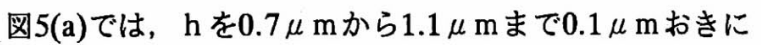
変えて計算しているが, エミッション電流, 電界強度は, ともに $\mathrm{h}=1.0 \mu \mathrm{m}$ のときに最大值となっている。ゲート電 極上面の高さが $1.0 \mu \mathrm{m}$ であることから, エミッ夕電極の高 さが, ゲート電極上面の高さに等しいとき, 最大のエミッ ション電流が得られることがわかる。伊藤氏らはエミッ夕 電極先端の電界強度は, エミッ夕電極の高さがゲート電極 上面の高さに等しくなるときに最大になるという計算結果 を得ており ${ }^{(9)}$, 我々が得た結果之一致する。

同図(b)からは発散角はこの h の範囲では大きな変化はな いと言える。

図6(a), (b)は, $\theta$ を $29^{\circ}$ から5 おきに小さくしたときの エミッション電流, 電界強度, 発散角を示している。これ らはいずれも $\theta$ の減少ととむに単調に增大し， $\theta=14^{\circ}$ のと きは， $\theta=29^{\circ}$ のときに比へててエミッション電流は 2 桁近く 增大している。エミッ夕電極先端の曲率半径が一定の場合 でも，半角が小さくなるとエミッション電流は大きく增大 すると同時に, 電子ビームの発散角は大きくなることがわ かる。

図7(a), (b)は，曲率半径 $\mathrm{r}$ を20nmから5 nmおきに小さく したときのエミッション電流, 電界強度, 発散角の変化を 示している。 r が5nm隇少するとエミッション電流は2析程 度增大しており，rの変化による影響が極めて大きいこと がわかる。また, $\mathrm{r}$ が小さくなると, 電子ビームの発散角 は大きくなることがわかる。

4. 集束電極付き冷陰極のシミュレーション

本冷陰極の電子ビーム源としての応用を考えた場合, 電子 ビームの発散を抑えることが重要である。ゲート電極の上 に集束電極を備えた構造の冷陰極を用いれば，電子ビーム の発散を㧕えることができる。図8は、この構造の泠陰極に ついての計算例を示しており, 集束電極を用いて電子ビ一

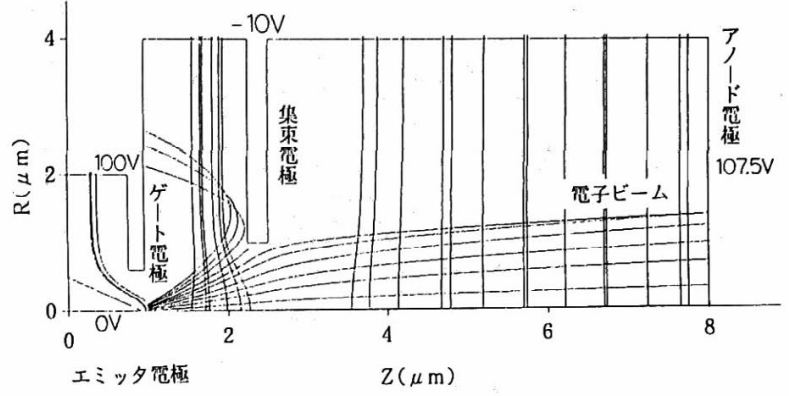

図8 集束電極付き冷陰極からの電子ビーム軌道計算例

Fig.8.A simulation example of electron beam trajectories from a field emitter with a focus gate.

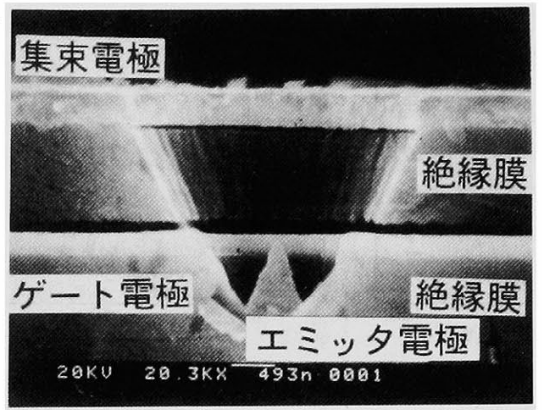

(a) 電子顕微鏡写真

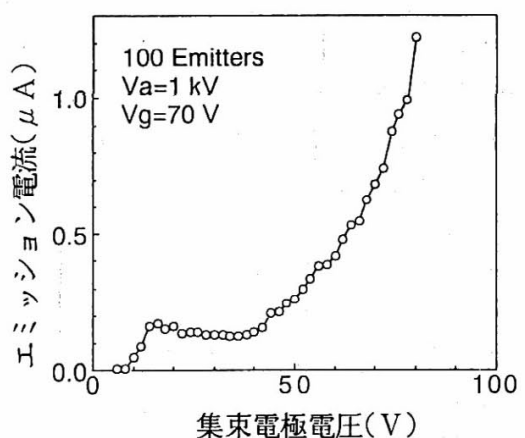

(b) エミッション電流の集束電極電圧依存性実験結果

図9作製した集束電極付き冷陰極およびエミッション特性

Fig.9.A fabricated field emitter with a focus gate electrode and its emission characteristic.

ムを集束可能であることがわかる。ここでは，この構造の 冷陰極について, エミッ夕電極の形状や仕事関数をパラメ 一タにとり, 集束電極電圧に対するエミッション電流を計 算し，実験結果との一致を試みる。

我々は，電子技術総合研究所と共同で集束電極を備えた 素子を作製し，集束電極にゲート電極に対して負の電圧を 印加して電子ビームを集束させる実験を行った。 ${ }^{(10)}$ 実験 に用いられた集束電極付き冷陰極の電子顕微鏡写真を図9 (a)に示す。これはn形シリコンウエハをRIEでエッチング し, 熱酸化によるエミッ夕電極の尖鋭化技術 ${ }^{(1)}$ を利用して 作製されたものである。エミッ夕電極の先端は,ゲート電 極の下面より高く，上面より低いことがわかる。また，工 


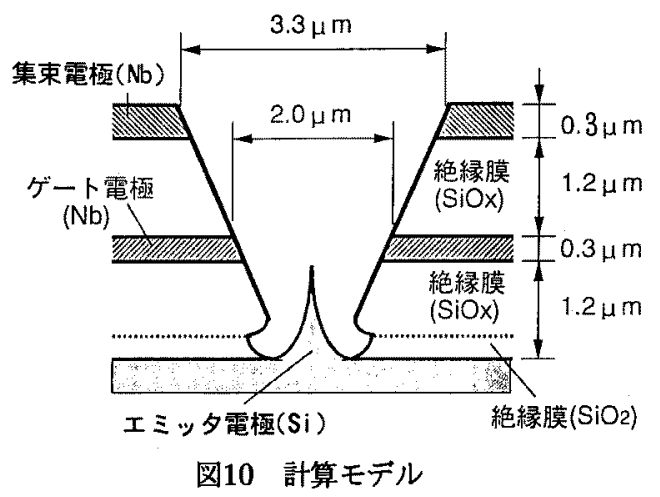

Fig.10.A simulation model

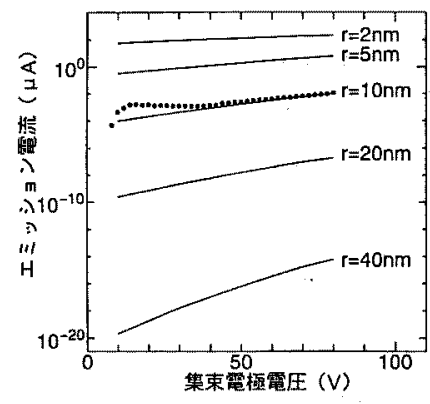

(a)縦軸 $\log$ スケール

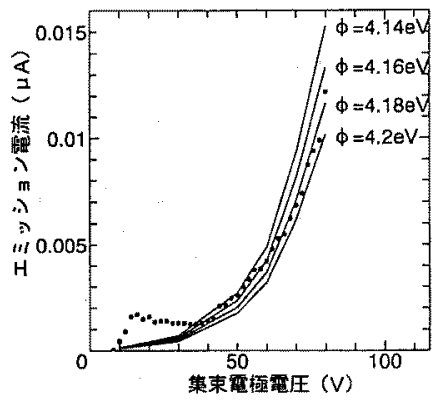

(b)縦軸linerスケール $(\mathrm{r}=20 \mathrm{~nm})$
図11 集束電極付き冷除極のエミッション電流と集束電極 電圧の関係(点線:実験結果, 害線:計算結果)

Fig.11.The emission current of a field emitter with a focus gate as a function of the focus gate voltage.(dotted line:an experimental result,solid lines:calculated results)

ミッタ電極上方から撮影した写真で、エミッ夕電極, ゲー 卜電極，集束電極がほぼ同心状に形成されていることを確 認した。

この素子において，ゲート電極電圧を70Vで一定とし， 集束電極電圧 $V_{\mathrm{f}}$ を $80 \mathrm{~V}$ から小さくしたときのエミッショ ン電流と $\mathrm{V}_{\mathrm{f}}$ の関係を図9(b)に示す。図中の100 Emittersは エミッ夕電極が100個ある素子を用いたことを示し，Vaは アノード電圧，Vgはゲート電圧を示す。電子ビーム径が 小さくなる(図示なし) と同時に，エミッション電流も小 さくなっている。これは集束電極電圧を小さくすることに よりエミッ夕電極表面の電界強度が小さくなったためと考 えられる。また，実験結果で集束電極電圧が40V以下の之 ころでdI/dV $\mathrm{dV}_{\mathrm{f}}$ 負になっているところがあるが,このよう な結果になった理由は現在のところ不明である。

以下では，この形状の冷陰極に関するEGN2を用いたシ ミュレーション結果について述へるととむに，シミュレー ション結果と図9(b)に示した実験結果（ただし，以後の計 算結果と実験結果の比較の図では，実験結果のデータはエ ミッタ電極 1 個あたりのエミッション電流に換算されてい る。との比較について述べる。

4-1. 計算モデル

図10に計算モデルを示す。この形状は罒9(a)に示した電 子顕微鏡写真をもとにしている。エミッ夕電極の高さは

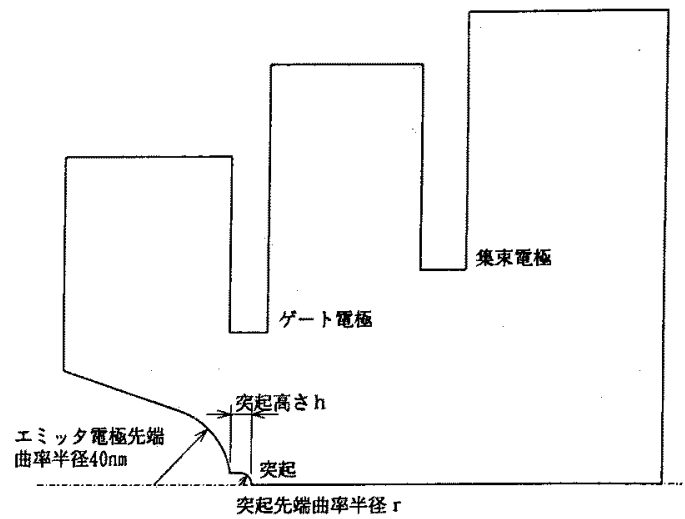

(a) モテル形状

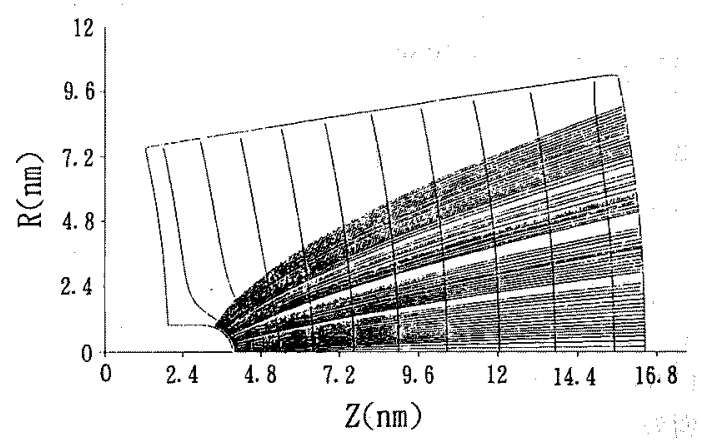

(b)エミッタ電極先端近傍の電子軌道計算例 図12 突起付き冷陰極

Fig.12.Field emitter with a bump.

$1.4 \mu \mathrm{m}$ である。ゲート電極，集束電極の開口部直径はそ れぞれ $2.0 \mu \mathrm{m}, 3.3 \mu \mathrm{m}$ であり,ゲート電極厚さ，集束電 極厚さはともに $0.3 \mu \mathrm{m}, 2$ 層ある絶縁膜厚さはともに1.2 $\mu \mathrm{m}$ である。エミッ夕電極先端の曲率半径は，電子影微鏡 写真から40nm程度と推定した。しかし，実験でエミッシ ョン電流の測定に用いられた素子にはエミッ夕電極は 100 個あり，その中にはさらに小さな曲率半径のエミッ夕電極 がある可能性むあるので，曲率半径として2，5，10，20, $40 \mathrm{~nm}$ にいて計算する。また, シリコンの仕事関数は 4.2 . $\mathrm{eV}^{(\eta)}$, ゲート電圧は $70 \mathrm{~V}$ とする。

\section{4-2. 計算結果}

集束電極電圧 $\mathrm{V}_{\mathrm{f}}$ を $10 ， 30 ， 50 ， 60 ， 70 ， 80 \mathrm{~V}$ と変化させ たときのエミッション電流值の計算結果を図11(a)に示す。 図中，点線は実験結果を示している。曲率半径 $10 \mathrm{~nm}$ の きの計算結果が実験結果に最も近くなっている。実験結果 と計算結果（曲率半径10nm）を，縦軸をリニアに書き直 すと図11(b)のようになる。この図に，形状は変えず， シ リコンの仕事関数を4.18，4.16，4.14eVと変化させて計算 した結果をあわせて示す。図11(b)では，計算結果はエミ ッション電流の絶対値に関して実験結果と同程度の值が得

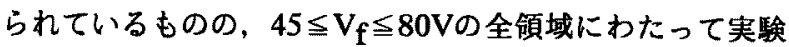
結果によく一致する曲線がなく，計算結果と実験結果とは よく一致しているとは言いがたい。 


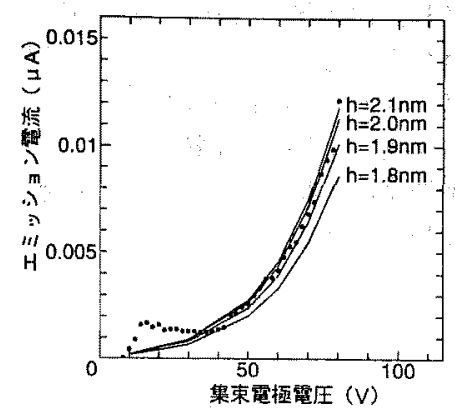

图13 エミッタ電極先端に突起の存在を仮定した場合のエミッシ ヨン電流亡集束電極電厈の関係(点線:実験結果, 実線:計算 結果, 仕事関数 $4.2 \mathrm{eV}$ )

Fig.13.The emission current of a field emitter with a bump as a functoin of the focus gate voltage(detted line: an experimental result,solid lines:calculated results, work function $=4.2 \mathrm{eV}$ )

エミッタ電極先端の曲率半径および仕事関数を様々に変 化させたが, 実験結果とよく一致する結果が得られなかっ た。これまでは，エミッ夕電極先端は球面として計算して いたか，次に他の形状を考虑することで計算結果と実験結 果の一致を試みる。

4-3. エミッ夕電極先端に架起の存在を考虑した計算 エミッ夕電極先端に, 図12(a)に示すような微小な突起 が存在するものとして計算を行う。突起の先端部分の電界 強度は, エミッ夕電極の他の部分より十分大きく，電子の 放出はこの部分のみを考虑すればよい。突起先端部近傍で の電子の軌道を図12(b)に示す。

エミッ夕電極先端の曲率半径を $40 \mathrm{~nm}$ とし, 乫起のアス ペクト比を $2,2.5,3$, 突起の高さhを $1.8 ， 1.9,2.0$,

$2.1 \mathrm{~nm}$ と変化させる。

それぞれの形状について，集束電極電压 $\mathrm{V}_{\mathrm{f}}$ 10，30,

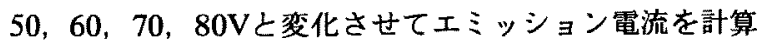
した。アスペクト比2の上きに実験結果と最もよい一致が 得られたので，この場合の結果を実験結果とともに図13 に示す。

実験結果と比較して，高さhが2.0nmあるいは1.9nmの ときの計算結果が，エミッション電流の絶対値，および集 束電極電圧 $\mathrm{V}_{\mathrm{f}}$ の変化に対するエミッション電流の変化の 割合の両方について, $45 \leqq V_{\mathrm{f}} \leqq 80 \mathrm{~V}$ 広い範囲にわたっ てよく一致している。

突起の高さが $2.0 \mathrm{~nm}$ のさには突起先端曲率半径は 1.0 $\mathrm{nm}$ となり, 突起の断面内の原子数は10個程度になるため, 厳密に電子故出を論じるには一つ一つの原子配置を考虑し た理論的解析が必要と思われる。しかし、これまで発表さ れている実験データは，Fowler-Nordheimプロットに従 うちのであったと報告されていることから，本論文では Fowler-Nordheimの式を用いてエミッション電流を評価 している。

また，実際上はエミッタ電極表面には複数個の微小な突 起や凹凸があり，これらから電子が放出されていると考え
られる。EGN2は軸対称2次元プログラムであるため, 上記の 複数個の微小な突起や凹凸を, エミッ夕電極先端に置かれた1 個の突起で代表させて計算している。

電子の電界放出に影搖を与える要因には，電極表面の電界 強度と電極材料の仕事関数とがあり，電極形状は電界強度を 決める重要な因子である。

本論文で得られた結果から，仕事関数を変えずに，電極形 状を適切に選ぶことによって，エミッション電流の計算結果 と実験結果とをよく一致させ得ることがわかった。

5. まとめ

電子銃解析コードEGN2を用いて，電界放出微小泠陰極から の電子放出のシミュレーションを行った。鋭く尖ったエミッ 夕電極先端からの電界放出による電子の放射に関して検討し, 以下の結果を得た。

(1)エミッ夕電極とゲート電極からなる冷陰極について, 低 電圧で大きなエミッション電流を得るには，エミッタ電極の 高さをゲート電極の上面の高さに一致する程度にすればよい こと, エミッ夕電極の半角および曲率半径は小さいほどよい ことがわかった。これにより，エミッ夕電極形状設計のため のひとつの指針が得られた。

(2)集束電極を備えた泠陰極において，集束電極電圧のエミ ッション電流に与える影響を計算し，実駘結果と比較した。 エミッ夕電極先端に微小突起の存在を仮定して計算した場合, 計算結果之実験結果とがよく一致する突起形状が得られた。 これは，冷陰極において，電子はエミッ夕電極先端の全面か ら放出されているのではなく，限られた場所から放出されて いるとする考えを支持するむのである。

本論文で得られた結果から，仕事関数を変えすに，電極形 状を適切に選ぶことによって，エミッション電流の計算結果 と実験結果とをよく一致させ得ることがわかった。

集束電極を備えた冷陰極については，今後電子ビーム径や エミッタンスの検討なども必要であると考える。

6. 謝辞

集束電極付き素子の作製にあたってご助言をいただき，貴 重な測定結果を提供くださった電子技術総合研究所伊藤順司 氏，金丸正哃氏に梁く感謝いたします。 （平成6年9月5日受付，平成7年7月3日再受付） 


\section{文献}

(1) 横尾邦義:「真空マイクロエレクトロニクス - 新 しい真空素子の世界 $-」$, 電学誌, 112 巻4号, pp. 257-262, 1992年

(2) C.A.Spindt,I.Brodie,L.Humphery, and E.R.Westerberg:"Physical properties of thin-film field emission cathodes with molybdenum cones",J.Appl. Phys.,vol.47,pp.5248-5263,1976

(3) I.Brodie and J.J.Muray:"The Physics of Micro/ Nano-Fabrication",Plenum Press, New York,1992

(4) W.B.Herrmannsfeldt,R.Becker,I.Brodie,A.Rosengreen, and C.A.Spindt:"High-Resolution Simulation of Field Emission",Third International Conference on Charged Particle Beams, Toulouse,France,Apr., 1990

(5) Richard M.Mobley and J.E.Boers:"Computer Simulation of Micro-Triode Performance",IEEE Trans. on Electron Device,vol.38,No.10,pp.2383-2388, Oct.,1991

(6) T.H.P. Chang, D.P. Kern and M.A. McCord:"Electron optical performance of a scanning tunneling microscope controlled field emission microlens system",J.Vac.Sci.Technol.B7(6),pp.1855-1861, Nov/Dec,1989

(7) 物理定数表, 朝倉書店,1986

(8) Technical Digest 4th Int. Vacuum Microelectronics Conf.(Nagahama, Japan), 1991

(9) J.Itoh and H Hiroshima:"Fabrication and theoretical study of micronize vertical vacuum triodes", Inst. Phys. Conf. Ser. No.99: Section7, 2nd Int. Conf. on Vac. Microelectron., Bath, 1989

(10)森川, 金丸, 伊藤:「電界放射エミッ夕を利用した 高輝度微小電子銃の試作(3)」, 第54回応用物理学 会学術講演会講演予稿集 $27 \mathrm{p}-\mathrm{Y}-1,1993$ 年秋季

(11)K.Betsui:"Fabrication and characteristics of Si field emitter arrays", Technical Digest 4th Int. Vacuum Microelectronics Conf.(Nagahama,Japan), pp.26-29,1991
浅野 啓行 （正員）1960年4月2日生まれ。86年3月名古屋 大学大学院工学研究科電気電子専攻博士前期 課程修了。同年4月三菱電機（株）入社。現在, 先端技術総合研究所勤務。高周波発振管の研 究開発に従事。プラズマ・核融合学会, 応用 物理学会会員。

菊永 敏之 （正員）1955年4月2日生まれ。83年3月東京工 業大学大学院理工学研究科電気・電子工学専 攻博士課程修了。工学博士。同年4月三菱電機 （株）入社。現在, 先端技術総合研究所勤務。 プラズマ・核融合関連機器の研究開発に従事。 電気学会, 物理学会, プラズマ・核融合学会 会員。

森川 和敏 （非会員）1961年5月1日生まれ。86年3月九州 大学大学院工学研究科電気工学専攻博士前期 課程修了。同年4月三菱電機（株）入社。現在, 先端技術総合研究所勤務。真空マイクロ素子 の研究開発に従事。応用物理学会会員。 